\title{
Series
}

\section{空から見る日本の地すべり地形シリーズー47ー Aerial watching of landslides in Japan -47-}

\section{山形県蔵王火山群・酢川最上流部で後期更新世に発生した大規模火山体崩壊}

\section{Late Pleistocene sector collapse of Zao volcano in the upper most reaches of the Sukawa river, Yamagata, northeast Japan}

八木浩司 Hiroshi YAGI/山形大学 Yamagata University

井口 隆 Takashi INOKUCHI/防災科学技術研究所 National Research Institute for Earth Science and Disaster Resilience

キーワード : 大規模火山体崩壊, 後期更新世, 水蒸気爆発, 蔵王火山, 酢川

Key words : Sector collapse, the late Pleistocene,phreatic explosion, the Sukawa river, Zao volcano

\section{1. はじめに}

山形盆地南東, 蔵王温泉が位置する酢川の源頭部は, 瀧山南面や鳥皃山西面を深くえぐるような, 比高300$500 \mathrm{~m}$ の急崖（以下本文では崩壊壁と呼ぶ）とそれに囲 まれた直径約 $2 \mathrm{~km}$ の広がりのある鍋底状の凹地形（以 下本文ではカルデラ状凹地形と呼ぶ）を呈している（写 真 $-1,2,3$; 口絵 $-1,2,3)$ 。また, 酢川に沿って流山地 形が下流側の上山（かみのやま）にかけて残され，“酢 川泥流“とよばれてきた岩屑なだれ堆積物も確認出来る (図 -1 ; 写真 -4 : 口絵 -4 )。この岩屑なだれ堆積物に は, 長径数 $\mathrm{m} \sim 十$ 数 $\mathrm{m}$ の安山岩ブロックが卓越的に含ま れる。このため酢川源頭部の大きなカルデラ状凹地形は, 火山体の大崩壊の結果形成されたものと考えられてきた (阿子島・山野井, 1985 ; 八木ほか, 2005)。山形蔵王ス キー場は, 崩壊壁やその基部に広がる緩やかな斜面に開 発されたものである。それは, スキー場ゲレンデがカル デラ状凹地形の中央部に向かって集まってくることから

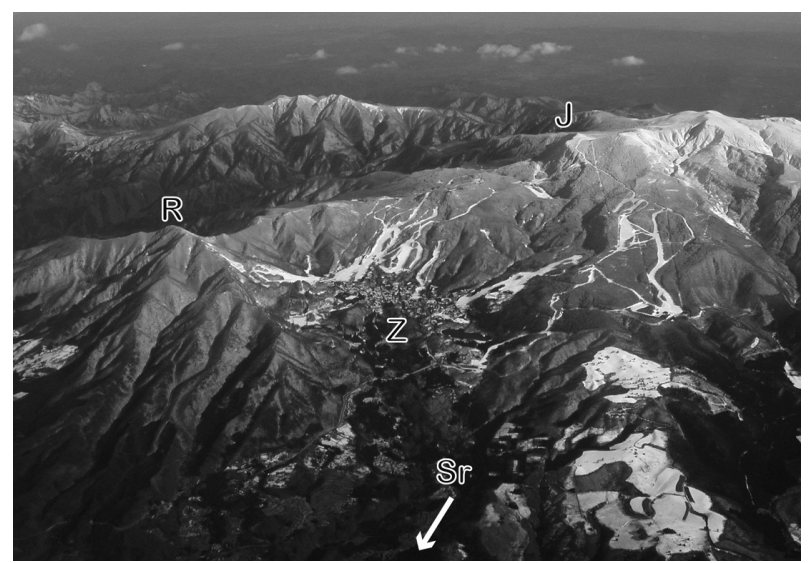

写真-1 蔵王火山群及び酢川最上流部のカルデラ状凹地形 (蔵王山田上空から東方向に撮影)

$\mathrm{J}$ : 地蔵岳 $\mathrm{R}$ : 瀧山 $\mathrm{Z}$ : 蔵王温泉 $\mathrm{Sr}$ : 酢川 酢川（Sr）最上流部にあたる画面中央のスキー 場ゲレンデや集落（蔵王温泉街：Z）の位置する 鍋底状凹地形が, 巨大火山体崩壊によって形成さ れた.

\section{も理解できる（写真 -1$)$ 。}

このカルデラ状凹地形の形成時期については，岩首な だれ堆積物の閉塞によって形成された湖沼を埋積する積 物中のテフラから，少なくとも 7 万年前以前に遡ると考 えられている（八木ほか, 2005）。同凹地形内に山体崩壊 後の新たな火山噴出物は認められていないことから，こ の崩壊の直接的原因は, 水蒸気爆発と考えられる。

\section{2. 酢川最上流部の山体崩壊の規模と二次的な滑落崖}

この山体崩壊の規模は，岩屑なだれ堆積物の面積とそ

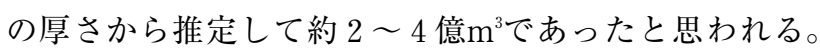
現在の瀧山（標高 $1362 \mathrm{~m} ）$ の南縁に接してもとの山体が あったと仮定した場合, 等価摩擦係数 $(\mathrm{H} / \mathrm{L})$ は0.12程 度となる。岩屑なだれ堆積物は, 上山市街西側にある丘 陵に乗り上げるようにしてとまっていることから，等価 摩擦係数は, ここで示したものよりも若干低くなる可能 性もある。しかし, 経験的に知られる巨大山体崩壊の規 模とそれとの対応はよい（例えば奥田, 1984）。

写真 -3 上に認められる, 地蔵岳 $(\mathrm{J})$ 北面から横倉山

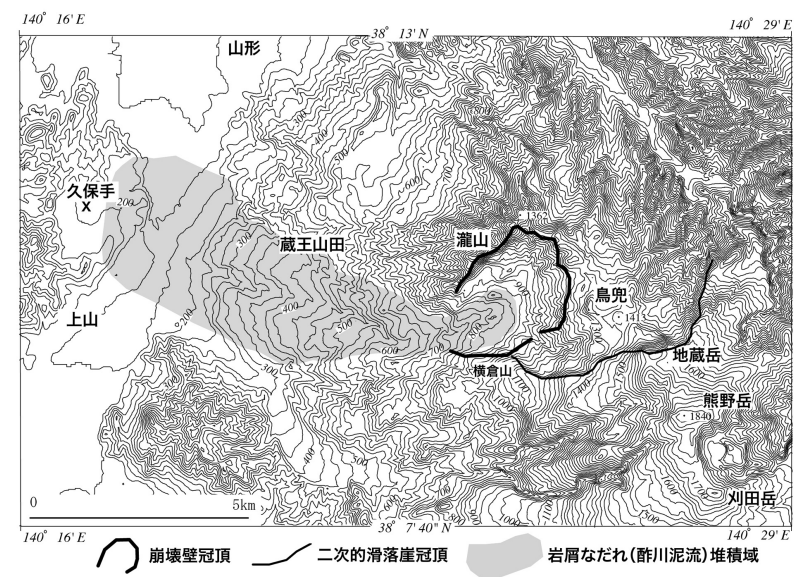

図-1 酢川流域および蔵王火山周辺の地形概念

国土地理院発行数值地図 $(50 \mathrm{~m}$ メッシュ)・仙台か ら作成. 等高線間隔 $25 \mathrm{~m}$ 


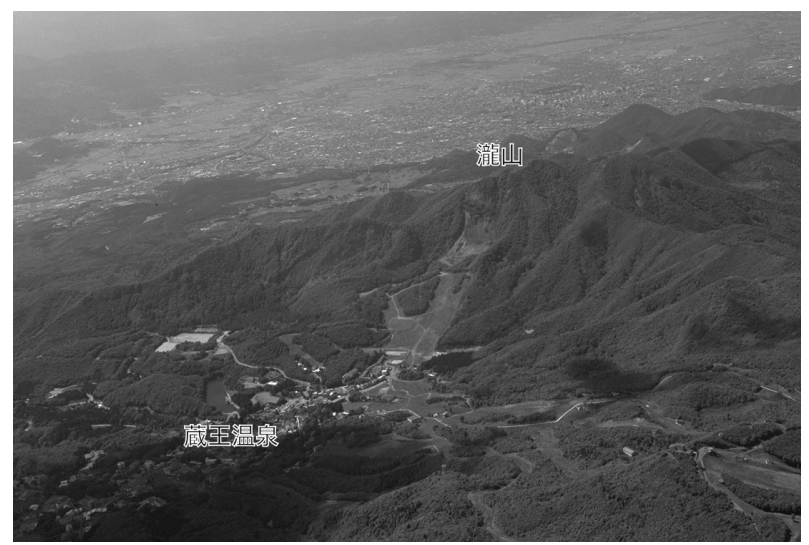

写真一2 瀧山南面のカルデラ状凹地形 (地蔵岳上空から北西方向に撮影)

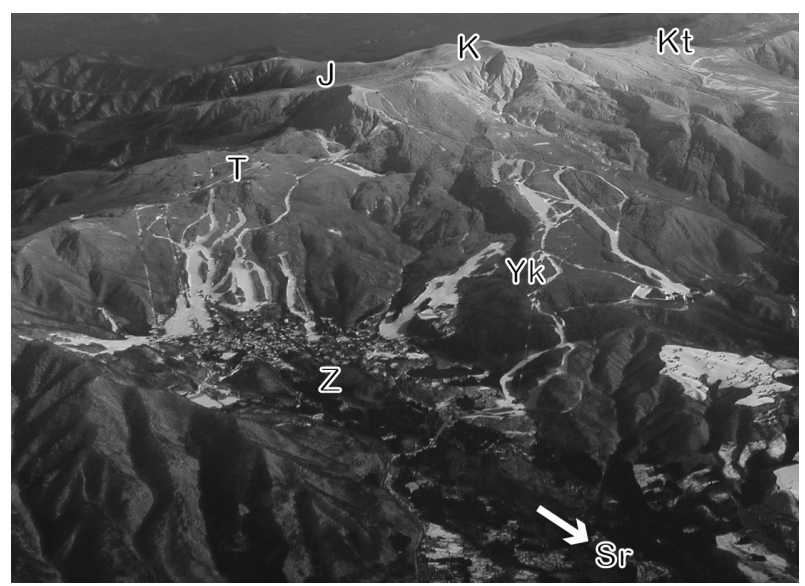

写真一3 蔵王火山群とカルデラ状凹地形及び二次的に発達 した滑落崖（蔵王山田上空から南東方向に撮影） $\mathrm{J}$ : 地蔵岳 $\mathrm{K}$ ：熊野岳 $\mathrm{Kt}$ ：刈田岳 $\mathrm{T}$ ：鳥兒 $\mathrm{Yk}$ ：横倉山 $\mathrm{Z}$ : 蔵王温泉 $\mathrm{Sr}$ ：酢川 画面右上から中央上にかけて連なる緩やかな稜線 が, 蔵王火山群を構成する. 右から蔵王火山群の 刈田岳 $(\mathrm{Kt})$, 熊野岳 (K), そして地蔵岳 (J) で ある. 地蔵岳の北面は切り立った急崖（影の部分） となり西側に連なっている.

（Yk）まで延びる大きな影の帯は，比高100～150mの急 崖となっている。この急崖は, 地蔵岳北面や地蔵岳から

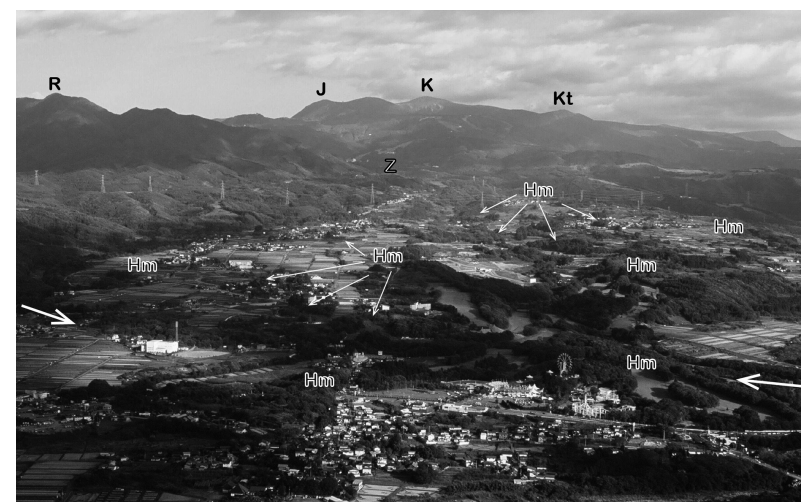

写真－4 蔵王火山群から西〜北西に流下する酢川岩屑なだ れ堆積面（上山市久保手上空から東～東南東方向 に撮影)

$\mathrm{Hm}$ ：流山地形 $\mathrm{J}$ : 地蔵岳 $\mathrm{K}$ : 熊野岳 $\mathrm{Kt}$ ：刈 田岳 $\mathrm{R}$ : 瀧山 $\mathrm{Z}$ : 蔵王温泉

画面中央の扇状に広がる流山（Hm）を載せる丘 陵地形が, 岩屑なだれの堆積面. 岩屑なだれ堆積 面は，画面中の矢印を結んだ位置に沿って走る活 断層で変位している.

西に下る溶岩流堆積面北縁を限って（図-1 の二次的滑 落崖冠頂), 約 $3 \mathrm{~km}$ にたって連続する (図 - 1, 写真一 $3)$ 。この急崖は, 噴出時期 $30-10$ 万年前の中央蔵王第 3 期噴出物（酒寄, 1992）の堆積面を断ち切るように発 達することから，年代的に酢川最上流部の大規模火山体 崩壊に起因する二次的な山体変形に伴う滑落崖と考えら れる。この二次的滑落崖の成因がいかなるものであろう と, 現在そこにはゲレンデが開かれ, スキーヤーやスノー ボーダーの腕の見せ所となっている。

\section{引用文献}

阿子島功 ・ 山野井徹（1985）蔵王火山西麓の酢川泥流の発生時期. 東北地理, 37, 159- 165 .

奥田節夫（1984）歴史的記録からみた大規模崩壊の土石堆積状態 の特性．京大防災研年報, $27 \mathrm{~B}-1,353-368$.

酒寄敦史（1992）蔵王火山の地質と岩石. 岩鉱, 87, 433-444.

八木浩司 - 早田勉 - 井口隆 - 原口強 - 伴雅雄 (2005) 蔵王火山及 び白鷹火山の巨大山体崩壊発生時期. 第四紀研究, 44, 263-272.

(原稿受付2017年 1 月 20 日，原稿受理2017年 1 月20日） 